|Volume: 5 | Number: 2 | October 2020| E-ISSN: 2503-4405|P-ISSN: 2580-3441|

\title{
Using Speech Function on EFL Classroom
}

\author{
Muhammad Saibani Wiyanto \\ STKIP PGRI Jombang \\ msaibaniw@gmail.com
}

\begin{abstract}
This study deals with the utterances of an English teacher of SMP A. Wahid Hasyim Tebuireng. It is aimed to know the type of speech function used by the English teacher in the classroom, and to find out how speech functions are applied by an English teacher in the classroom. The researcher applies qualitative approach and content analysis design based on Ary et al (2010). The subject of this research was an English teacher in SMP A. Wahid Hasyim Tebuireng. The source of the data is the subject in which the data are obtained, while the data are the utterances used by the English teacher. The researcher used observation and audiovisual material of collecting data. The data of transcription are classified into six basic types of speech function; they are expressive, directive, referential, metalinguistic, poetic, and phatic. From the teacher who was observed, the researcher found different total of utterances from each meeting. The total utterance is 41 utterances which are classified into five types of speech function. How the speech functions are applied by the English teacher in the classroom is when the teacher interacted with her students.
\end{abstract}

Keywords: Classroom, English Teacher, Speech Function

\section{INTRODUCTION}

Every human being needs language to communicate with others because human is social creatures. Without language, it is impossible for humans to interact with others. The daily activities of humans also use a language. These activities include asking friends, listening to teachers' explanations, presentations, and other activities. Language allows us to speak, read, write, listen, and even for us to think. According to Halliday (1994: xiii) language is structured to make three kinds of meanings, or metafunctions, simultaneously: ideational, interpersonal, and textual meanings.

There are many languages in the world, but English becomes International language learned by all countries. With English, communication towards each other country becomes easier. It is important for us to learn language because language is needed to communicate with other communities. A message will be delivered with social interaction and communication by using language. There is a relationship between language and society, it is tool of communication with each other. Learning sociolinguistics is one of the ways to know that language used by society. Sociolinguistics is study about relationship between language and society. 
Sociolinuistics studies relationship between language and society. It is Interested in explaining why we speak differently in different social contexts, and they concern with identifying the social functions of language and the ways it is used to convey social meaning. Examining the way people use language in different social contexts serves a wealth of information about the way language works, as well as about the social relationships in a community, and the way people convey and construct aspects of their social identity through their language (Holmes, 2013: 1). While, according to Hudson (1997: 5) sociolinguistic studying the relation between both language and society.

Speech function is one of sociolinguistics part. Speech function explains the social function of speech. It means there are different function of speech. According to Holmes (2013: 275) there are many type of language function. They are expressive, directive, referential, metalinguistic, poetic and phatic. People produce speech has different function.

In this case, the researcher interested in analyzing the speech function used English teacher in the classroom. It aims to know the type of speech function that used by English teacher in classroom of SMP A. Wahid Hasyim. So that communication between teacher and student is well established and also can give a contribution in the field of education especially for English teacher.

\section{METHOD}

In this article the researcher used qualitative research and content analysis used here as one type of qualitative research. According to Ary (2010: 48) content analysis focuses on analyzing and interpreting record material to learn about human behavior. The researcher chose content analysis as research design to obtain information which delivered by a English teacher. The source of the data were the English teacher in SMP A. Wahid Hasyim Tebuireng. And the data are the utterances of the English teacher in SMP A. Wahid Hasyim. The instrument of the research was observation (observer non participant) and audiovisual material. The researcher used non participant observer to collect the data, reading through all the data, categorizes the teacher's utterances in to type of speech function used Holmes' theory by giving codes. The codes were EX: Expressive Function, DI: Directive Function, RE: Referential Function, ME: Metalinguistic Function, PO: Poetic Function, PH : Phatic Function. Because of the researcher needing two meetings. It needed the code for fist meeting (FM) and second meeting (SM). The last steps were analyzes the data of classification, analyze how teacher applied speech function in the classroom, and make conclusion.

\section{RESULTS AND DISCUSSION}

The findings are the result of data analysis about types of speech function used by the English teacher in classroom which are taken from data transcription as guidance to discuss data analysis. The data presented are the result from observation sheet. Findings of the research data are presented below:

\section{ENGLISH EDUCATION}

Journal of English Teaching and Research 


\section{The types of speech function used by English teacher in classroom}

From the analysis, the researcher displayes the data into a chart that shows types of speech function as follow:

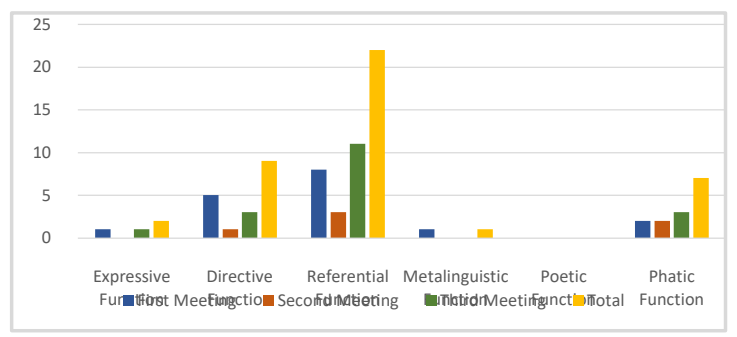

Figure 1. Types of Speech Function

In the present findings the researcher found that the English teacher used 5 types of speech function (expressive, directive, referential, metalinguistic and phatic function). The result was revealed to answer statement of the problem 1. This chart show how many speech functions the teacher used from the total 41 utterances. From this chart there are 2 utterances that belong to expressive function that is 1 type of speech function in the first meeting and 1 utterance type of speech function in the third meeting. 6 utterances that have directive function are found that is 5 utterances in first meeting and only 1 utterance in second meeting used by the teacher for interaction with her students in the class of eight C. 22 utterances were found to express referential function. They are 8 utterances in first meeting, 3 utterances in second meeting and 11 utterances in the third meeting. One utterance was found to have metalinguistic function. This utterance was used by the teacher in the first meeting. Then, 7 utterances were found to show phatic function. These 2 utterances were used in the first meeting, 2 utterances were in the second meeting and the other 3 utterances were used in the third meeting.

\section{a. Expressive Function}

This type of speech function, Holmes (2013) was used by the English teacher in 2 utterances. This is the same with Erawati's finding (2016) that found expressive function in the utterances used by English teacher. This function is used for expressing the teacher's feelings. In this function, the researcher found 2 utterances used by the English teacher, they are: (EX1/FM) and (EX2/TM). For example is the utterance "Good." The utterance belongs to expressive function because it expresses the teacher's feeling, she is satisfied to her students so that she appreciates them by saying "Good."

\section{b. Directive Function}

This type of speech function, Holmes (2013) says that directive function as utterances attempt to get someone to do something. In this finding the teacher used this function in all meetings. The teacher used the directive function in classroom occurs nine times of forty-six the data found, they are (DI1/FM), (DI2/FM), (DI3/FM), (DI4/FM), (DI5/FM), (DI6/SM), (DI7/TM), (DI8/TM), (DI9/TM). For the example of data (D17/TM) the utterance "Now please write in your book!" belongs to directive function. The teacher asks the student to do something that is 
|Volume: 5 | Number: 2 | October 2020| E-ISSN: 2503-4405|P-ISSN: 2580-3441|

to write the notes on their book. The utterances above are the example of directive function in imperative form.

\section{c. Referential Function}

According to Holmes (2013) referential function is utterances which provide information. Based on the data, the teacher used this function to get information or gave information to her students. There are 22 utterances produced by English teacher. This function in finding (RE1/FM), (RE2/FM), (RE3/FM), (RE4/FM), (RE5/FM), (RE6/FM), (RE7/FM), (RE8/FM), (RE9/SM), (RE10/TM), (RE11/SM), (RE12/SM), (RE13/TM), (RE14/TM), (RE15/TM), (RE16/TM), (RE17/TM), (RE18/TM), (RE19/TM), (RE20/TM), (RE21/TM), and (RE22/TM) For the example of data (RE9/SM) the utterance "For your score, exam score, I will give it in next meeting.". The utterance belongs to referential function because the utterance provides information. The teacher tells the students that their score will be given in next meeting.

\section{d. Metalinguistic Function}

For metalinguistic function, only 1 utterance used by the English teacher. The same as the finding from Erawati (2016) this function is occasionally used by the English teacher in classroom. In this research, the researcher found only one time of use from 46 data of the total data found that including metalinguistic function of English teacher's utterance. The utterance data containing metalinguistic function is (ME1/FM). It is "What is the meaning of special ocation?". The question above belongs to metalinguistic because it asks about the meaning of word in other language.

\section{e. Poetic Function}

Based on the data above, the researcher found that the English teacher used some types of speech function mentioned by Holmes (2013). It can be seen from the analysis that has been done by the researcher. But in this finding there is no utterances use for poetic function. According to Holmes (2013) poetic utterances focused on aesthetic features of language. This research analyzed the utterances used by English teacher in which the English teacher did not use poetic function.

\section{f. Phatic Function}

Speech function of phatic function is to express solidarity and empathy with others (Holmes: 2013). These utterances are used by the teacher for showing her solidarity and empathy to her students. This function was found in (PH1/FM), (PH2/FM), (PH3/SM), (PH4/SM), (PH5/TM), (PH6/TM), and (PH7/TM). For example, of data (PH1/FM) the utterance "Asalamu'alaikum Warahmatullahi Wabarakaatuh". The teacher expressed solidarity and empathy to the students by saying "Asalamu'alaikum Warahmatullahi Wabarakaatuh" before starting and leaving the class.

\section{How speech functions are applied by the English teacher in the classroom of SMP A. Wahid Hasyim}

Speech functions were applied by the English teacher in the classroom. How were the speech function applied by English teacher in the class? Speech functions can be used in the classroom when the teacher expresses her feeling, when she feels satisfied because the students answer the question. It includes expressive

\section{ENGLISH EDUCATION}

Journal of English Teaching and Research 
function. When the teacher attempted to get the students to do something for example, the teacher asked the students to start the class, it includes directive function.

When the teacher gave some explanation in the class, it includes referential function, because the utterance provides information. When the teacher asked the meaning of some words, it is how one of speech functions was applied by the English teacher in the class. One of that speech functions is metalinguistic function. The last is phatic function, this function are applied when the teacher asks of her student's condition of that day.

\section{CONCLUSION}

Based on the findings, the most dominant type of speech function used by English teacher in SMP A. Wahid Hasyim is referential function. The teacher uses this function to explain the material to the students, to give information or ask information to the students. There are 26 utterances of referential function produced by the teacher. Metalinguistic function is rarely used by the teacher in the classroom because it functions for commenting on language itself.

Speech functions are applied by the English teacher in the classroom when the teacher expresses her feelings, and when the teacher asks the students to do something. Also when the teacher gives some explanation, information and asks some question to the students or when the teacher asks the meaning of some words, and when the teacher is showing her solidarity and empathy to the students with asking their condition. The poetic function is not used by the teacher because the function is focused on aesthetic features of language.

Regarding this research which is about speech function used by English teacher as the object of this study, here, the researcher suggests for further researchers who are interested to continue this research that there are still a lot of types of speech function which cannot be found by the researcher. For the data of the analysis, it can be found such as from Twitter's account which uses English as the main language, English newspaper, English magazine, and others.

\section{REFERENCES}

Anugratamur, D. S. (2013). Speech Function in the Comic Entitled "Detective Conan". 21.

Ary, D. et.al. (2010). Introduction to Research in Education. Canada: Nelson Education, LTD.

Ball, J. (2005). The Routledge Handbook of Sociolinguistics Around the World. Oxon. Routledge.

Coulmas, F. (1998). The Handbook of Sociolinguistics. Florian: Blackwell.

Creswell, J. W. (2012). Educational Research (Fourth Edition). Boston: Pearson Education.

Halliday, M., \& Hasan, R. (1985). Language, Context and Text. Oxford: Oxford University Press.

Holmes, J. (2001). An Introduction to Sociolinguistics. Wellington: Pearson Education. 
| Volume: 5 | Number: 2 | October 2020|E-ISSN: 2503-4405|P-ISSN: 2580-3441|

Holmes, J. (2013). An Introduction to Sociolinguistics (Fourth Edition). New York: Routledge.

Hudson, R. (1997). Sociolinguistics. Cambridge: Cambridge University Press.

Meyerhoff, M. (2006). Introducing Sosiolinguistic. Cambridge: Cambridge University Press.

Moleong, L. (2012). Metodologi Penelitian Kualitatif. Bandung: PT Remaja Rosdakarya.

Rahmania. (2018). The Speech Function Used by Ibu Muslimah and Pak Harfan in "Laskar Pelangi" Drama. Post Graduate School, 1.

Santy, M. S. (2017). English Teachers'Strategies in Managing a Large Class at SMP Negri 4 Kota Jambi. 5.

Saragih, A. (2014). Discourse Analysis. A Systematic Functional Approaches to the Analysis of Texts. . Medan: Faculty Language and Art.

Wardhaugh, R. (1998). An Introduction to Sociolinguistic. Oxford: Blackwell.

Wardhaugh, R. (2006). An Introduction to Sociolinguistic. Oxford: Blackwell.

Wardhaugh, R. a. (2015). An Introduction to Sociolinguistics: Seventh Edition. West Sussex: John Wiley \& Sons.

Wiyanto, M. S., \& Asmorobangun, P. W. (2020). Gender differences of students' ability in writing descriptive text. JOLLT Journal of Languages and Language Teaching, 8(2), 153-161. DOI: https://doi.org/10.33394/jollt.v\%vi\%i.2314

Yule, G. (2003). The Study of Language: An introduction. Cambridge: Cambridge University Press. 